\title{
STUDI DOCKING MOLEKULAR SENYAWA TURUNAN KUINOLIN TERHADAP RESEPTOR ESTROGEN- $\alpha$
}

\author{
Mohammad Rizki Fadhil Pratama \\ Program Studi Farmasi, Fakultas Ilmu Kesehatan, Universitas Muhammadiyah \\ Palangkaraya, JI. RTA Milono Km.1,5 Palangka Raya, Kalimantan Tengah \\ e-mail : $\underline{\text { m.rizkifadhil@umpalangkaraya.ac.id }}$
}

\begin{abstract}
ABSTRAK
Estrogen- $\alpha$ (ER- $\alpha)$ merupakan target utama pada terapi kanker payudara jenis ER+. Inhibisi pada ER- $\alpha$ diketahui dapat memperlambat proliferasi sel kanker payudara ER+. Senyawa turunan kuinolin diketahui memiliki aktivitas antikanker dengan menghambat beberapa jenis reseptor. Belum diketahui apakah kuinolin dapat menghambat ER-a. Penelitian ini bertujuan untuk mengetahui interaksi antara ER- $\alpha$ dengan senyawa turunan kuinolin. Docking molekular terhadap ER-a menunjukkan bahwa kuinin memberikan energi bebas ikatan paling negatif dan konstanta inhibisi paling kecil, secara berturut-turut sebesar $-8,73 \mathrm{kcal} / \mathrm{mol}$ dan $0,398 \mu \mathrm{M}$. Hasil ini memberikan prediksi bahwa kuinin memiliki aktivitas sebagai inhibitor ERa dan memiliki potensi untuk dikembangkan pada terapi kanker payudara ER+. Meski demikian, afinitas yang ditunjukkan kuinin lebih rendah dibandingkan 4-hidroksitamoksifen, inhibitor poten ER- $\alpha$.
\end{abstract}

Kata Kunci : Docking, ER-a, Kuinin, Kuinolin.

\section{PENDAHULUAN}

Reseptor estrogen- $\alpha$ (ER- $\alpha)$ adalah salah satu biomarker utama selain human epidermal growth factor receptor 2 (HER2) yang memisahkan subkelompok biologis berbeda antara sel kanker dengan sel normal. Individu dengan overekspresi ERa akan memicu proses proliferasi berlebih pada sel payudara yang dikenal dengan kanker payudara ER+ (Moverare-Skrtic et al., 2013). Kanker payudara ER+ terjadi pada hampir $80 \%$ kasus kanker payudara (Pinhel et al., 2012).

Inhibisi pada ER- $\alpha$ menjadi salah satu target terapi pada penanganan kanker payudara ER+. Inhibitor ER- $\alpha$ yang telah dikenal dan digunakan dalam penggunaan secara klinis diantaranya tamoxifen yang bekerja langsung sebagai antagonis ER- $\alpha$ (Yamamoto-lbusuki et al., 2015). Berbagai antagonis ER- $\alpha$ telah dikembangkan untuk meningkatkan efektivitas terapi ER+ yang diberikan, namun hingga saat ini tamoxifen tetap menjadi pilihan utama dalam algoritma terapi kanker payudara ER+. Tamoxifen diketahui dapat menginduksi apoptosis pada sel kanker (Liu et al., 2014).

Kuinolin merupakan salah satu kelompok senyawa yang memiliki rumus kimia dasar $\mathrm{C}_{9} \mathrm{H}_{7} \mathrm{~N}$ dan memiliki aktivitas beragam seperti antimalaria, antimikroba, antikonvulsan, antiinflamasi, serta antikanker (Kumar et al., 2009). Beberapa jenis senyawa kuinolin dikenal karena aktivitas antimalarianya seperti klorokuin, 
kuinin, amodiakuin, primaquin, serta metabolit aktifnya seperti hidroksiklorokuin (Golden et al., 2015). Antimalaria golongan kuinolin selama ini diketahui juga digunakan dalam penanganan rheumatoid arthritis dan lupus erythematosus dimana penggunaannya diketahui dapat menekan perkembangan sel-sel abnormal pada penyakit tersebut. Studi bahkan menunjukkan bahwa kuinin memiliki aktivitas antikanker pada beberapa cancer line (Krishnaveni et al., 2016). Selain kuinin, ada potensi senyawa antimalaria golongan kuinolin lain contohnya klorokuin dan hidroksiklorokuin juga memiliki aktivitas antikanker seperti kanker payudara, kanker tenggorokan dan kanker rongga mulut (Singh \& Singh, 2014).

Penelitian ini bertujuan untuk menentukan antimalaria golongan kuinolin yang memiliki potensi untuk dijadikan terapi antikanker khususnya kanker payudara ER+. Turunan kuinolin dengan afinitas paling tinggi kemudian dibandingkan dengan antagonis ER- $\alpha$ yang telah diketahui.

\section{METODOLOGI}

Penelitian dilaksanakan secara in silico dengan metode docking molekular. Perangkat keras yang digunakan adalah Ultrabook ASUS seri A46CB dengan prosessor Intel core i5-3337U@1,8GHz dan sistem operasi windows 7 Ultimate 64-bit SP-1 (Pratama, 2016).

Reseptor yang digunakan adalah ER- $\alpha$ dengan 4-hidroksitamoksifen sebagai ligan co-crystal (PDB ID 3ERT). 4-hidroksitamoksifen atau afimoksifen adalah inhibitor ER- $\alpha$ yang telah diketahui dapat memperlambat proliferasi sel kanker pada kanker payudara dan saat ini digunakan sebagai gel topikal pada terapi kanker payudara ER+ (Mansel et al., 2007). Struktur molekul reseptor diperoleh website Protein Data Bank (PDB) www.rscb.org. Reseptor diunduh dalam format .pdb kemudian dihilangkan bagian yang tidak digunakan, diberi hidrogen nonpolar, diberi muatan, serta diatur posisi grid box dengan software AutoDockTools 1.5.6.rc3 (Morris et al., 2009).

Software docking yang digunakan dalam penelitian ini adalah Autodock 4.2.3 dari The Scripps Research Institute, Inc. (Morris et al., 2009). Metode yang digunakan untuk validasi proses docking adalah redocking dengan pose selection menggunakan struktur ligan co-crystal yaitu 4-hidroksitamoksifen sebagai pembanding. Redocking kemudian dilakukan terhadap 4-hidroksitamoksifen pada reseptor ER- $\alpha$. Parameter yang diamati pada proses validasi adalah RMSD dari ligan co-crystal pada sisi aktif yang dipilih. Software docking memberikan hasil yang lebih mendekati hasil eksperimental jika memiliki RMSD kurang dari $2 \AA$. RMSD yang makin kecil menunjukkan posisi ligan hasil redocking yang makin mendekati posisi ligan hasil kristalografi (Kontoyianni et al., 2011; Bissantz et al., 2000; Pratama, 2015; Nurhayati et al., 2015). 
Ligan yang digunakan adalah senyawa turunan kuinolin yaitu amodiakuin, hidroksiklorokuin, klorokuin, kuinin, dan primakuin. Struktur masingmasing ligan diskesta menggunakan software GaussView 3.08 dan dioptimasi geometri dengan menggunakan Gaussian 03W dari Gaussian, Inc. dengan metode ab initio Hartree-Fock basis set 6-311G. Optimasi geometri dilakukan untuk memperoleh konformasi paling ideal dari struktur senyawa yang disketsa dan mendekati bentuk alaminya (Cosconati et al., 2010).

Ligan yang telah dioptimasi dikonversi dari format .log menjadi format .pdb menggunakan software OpenBabel 2.3.2 (O'Boyle et al., 2011). Ligan lalu diberi muatan dan diatur torsinya menggunakan software AutoDockTools 1.5.6.rc3 (Morris et al., 2009).

Docking molekular pada ligan uji dilakukan dengan cara yang sama dengan proses validasi menggunakan ukuran dan posisi grid box yang sama. Parameter yang diamati untuk penentuan afinitas ligan terhadap reseptor adalah energi bebas ikatan $(\Delta G)$, konstanta inhibisi prediksi (ki), residu asam amino, serta jumlah ikatan hidrogen. Afinitas ligan terhadap reseptor ditentukan oleh nilai $\Delta G$ dan ki. Semakin negatif nilai $\Delta G$ dan semakin kecil nilai ki menunjukkan afinitas ligan yang semakin tinggi (Kim \& Skolnick, 2007). Ligan uji dengan residu asam amino dan ikatan hidrogen yang mendekati ligan alami menunjukkan kemiripan jenis interaksi dalam hal ini menggambarkan kemiripan aktivitas (Cosconati et al., 2010).

\section{HASIL DAN PEMBAHASAN}

Validasi proses docking dilakukan dengan metode redocking menggunakan Autodock 4.2.3. Validasi dilakukan terhadap sisi aktif dari ligan co-crystal yaitu 4-hidroksitamoksifen pada hasil kristalografi. Hasil redocking menunjukkan nilai RMSD sebesar $1,21 \AA$, yang menunjukkan bahwa posisi atom-atom pada ligan dari hasil redocking tidak berbeda terlalu jauh dengan posisi pada ligan hasil kristalografi (Bissantz et al., 2000). Hasil tersebut menunjukkan bahwa reseptor 3ERT dapat digunakan untuk proses docking.

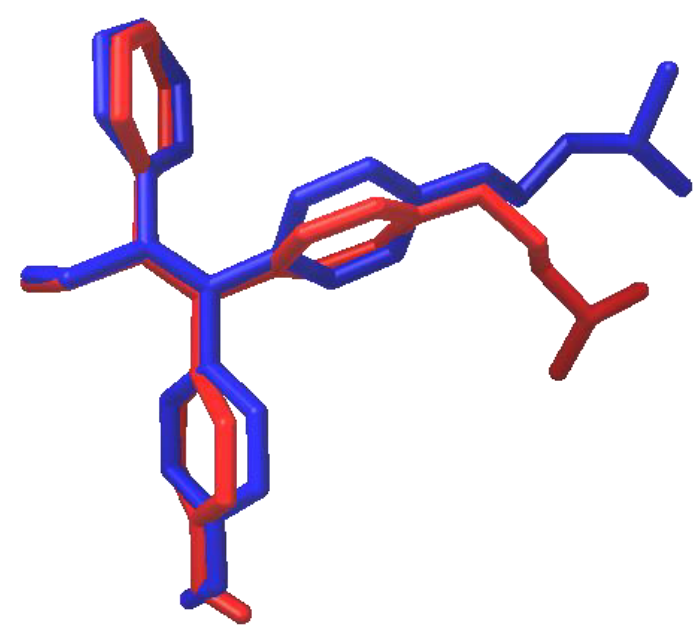

Gambar 1. Overlay posisi ligan hasil redocking 4-hidroksitamoksifen dengan hasil kristalografi (Merah = hasil kristalografi; Biru = hasil redocking)

Parameter lain yang diamati dalam proses validasi adalah $\Delta \mathrm{G}, \mathrm{ki}$, residu asam amino, 
serta jumlah ikatan hidrogen dari ligan cocrystal. Hasil yang ditampilkan pada tabel 1 menunjukkan terdapat 13 residu asam amino dengan 2 ikatan hidrogen antara ER- $\alpha$ dan 4-hidroksitamoksifen.

Tabel 1. Hasil validasi ER- $\alpha$ dengan ligan cocrystal 4-hidroksitamoksifen

\begin{tabular}{|c|c|}
\hline Reseptor & 3ERT \\
\hline Ligan & 4-hidroksitamoksifen \\
\hline RMSD $(\AA)$ & 1,21 \\
\hline$\Delta \mathrm{G}(\mathrm{kcal} / \mathrm{mol})$ & $-11,91$ \\
\hline $\mathrm{ki}(\mu \mathrm{M})$ & 0,00185 \\
\hline & 343-Met, 346-Leu, \\
& 347-Thr, 350-Ala, \\
351-Asp, 353-Glu, \\
Residu asam & 383-Trp, 384-Leu, \\
amino & 387-Leu, 394-Arg, \\
& 421-Met, 428-Leu, \\
& 521-Gly \\
\hline Jumlah ikatan hidrogen & 2 \\
\hline
\end{tabular}

Seluruh ligan uji sebagai ligan pembanding disketsa dan dioptimasi geometri menggunakan metode HartreeFock dengan basis set 6-311G. Metode tersebut merupakan pendekatan ab initio dengan tingkat kepercayaan yang relatif tinggi untuk pengerjaan secara in silico (Cosconati et al.,, 2010). Struktur 2 dimensi dan 3 dimensi dari seluruh ligan yang digunakan ditunjukkan pada tabel 2 .

Tabel 2. Struktur 2D dan 3D ligan

\begin{tabular}{|l|l|l|}
\hline Senyawa & Struktur 2D & Struktur 3D \\
\hline
\end{tabular}

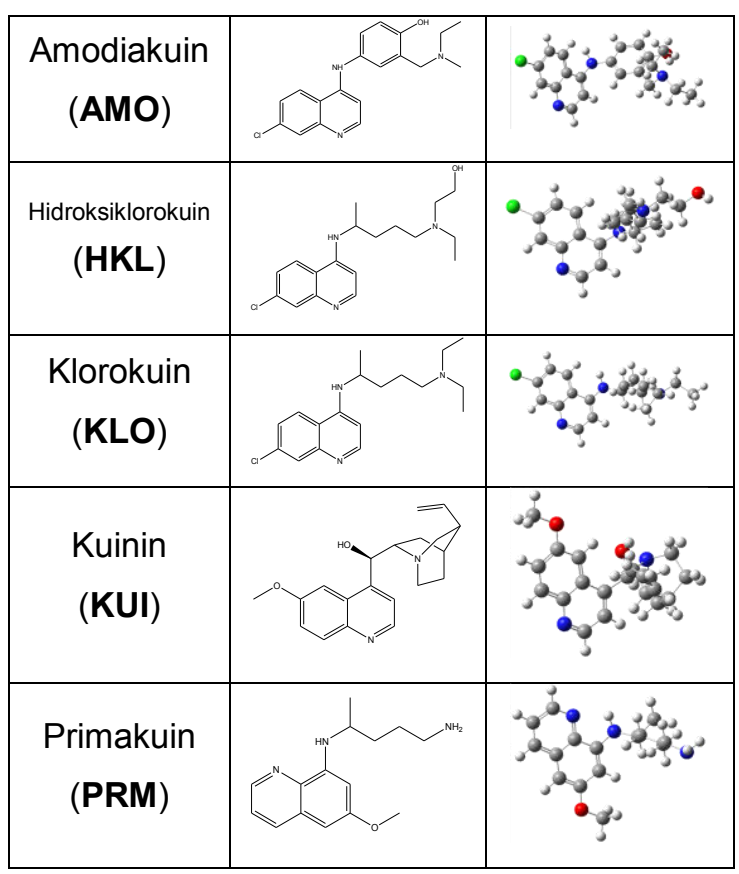

Docking molekular dilakukan terhadap seluruh ligan yang telah dioptimasi menggunakan Autodock 4.2.3 pada sisi aktif yang sama dengan yang digunakan pada proses redocking 4hidroksitamoksifen. Hasil docking dari seluruh ligan terhadap ER- $\alpha$ ditampilkan pada tabel 3.

Tabel 3. Hasil docking turunan Kuinolin terhadap ER- $\alpha$

\begin{tabular}{|c|c|c|c|c|c|}
\hline Ligan & AMO & HKL & KLO & KUI & PRM \\
\hline $\begin{array}{c}\Delta \mathrm{G} \\
(\mathrm{kcal} / \mathrm{mol})\end{array}$ & $-8,36$ & $-7,19$ & $-7,68$ & $-8,73$ & $-8,19$ \\
\hline $\begin{array}{c}\text { ki } \\
(\mu \mathrm{M})\end{array}$ & 0,774 & 5,38 & 2,36 & 0,398 & 0,995 \\
\hline $\begin{array}{l}\text { Residu } \\
\text { Asam } \\
\text { Amino }\end{array}$ & $\begin{array}{c}\text { - } \\
\text { 346-Leu } \\
\text { 347-Thr } \\
\text { 349-Leu } \\
\text { 350-Ala } \\
\text { 351-Asp } \\
\text { - } \\
\text { 354-Leu } \\
\text { 383-Trp } \\
\text { 387-Leu } \\
- \\
- \\
- \\
- \\
-\end{array}$ & $\begin{array}{c}\text { - } \\
\text { 346-Leu } \\
\text { 347-Thr } \\
- \\
\text { 350-Ala } \\
\text { 351-Asp } \\
- \\
- \\
\text { 383-Trp } \\
- \\
- \\
\text { 391-Leu } \\
\text { 394-Arg } \\
\text { 404-Phe } \\
\text { - }\end{array}$ & $\begin{array}{c}- \\
\text { 346-Leu } \\
347-T h r \\
- \\
\text { 350-Ala } \\
\text { 351-Asp } \\
- \\
\text { 354-Leu } \\
\text { 383-Trp } \\
\text { 387-Leu } \\
- \\
- \\
\text { 394-Arg } \\
\text { - } \\
\text { - }\end{array}$ & $\begin{array}{c}\text { 343-Met } \\
\text { 346-Leu } \\
- \\
- \\
\text { 350-Ala } \\
- \\
\text { 353-Glu } \\
- \\
- \\
\text { 387-Leu } \\
\text { 388-Met } \\
\text { 391-Leu } \\
\text { - } \\
\text { - } \\
\text { 420-Gly }\end{array}$ & $\begin{array}{c}\text { 343-Met } \\
\text { 346-Leu } \\
\text { 347-Thr } \\
\text { 349-Leu } \\
\text { 350-Ala } \\
\text { 351-Asp } \\
\text { 353-Glu } \\
- \\
- \\
- \\
- \\
- \\
- \\
404-\text { - } \\
-\end{array}$ \\
\hline
\end{tabular}




\begin{tabular}{|c|c|c|c|c|c|}
\hline & - & - & - & - & $421-M e t$ \\
& - & - & - & $424-$ Ile & $424-$ lle \\
& - & - & - & $428-$ Leu & - \\
& - & - & - & $521-$ Gly & - \\
& $525-$ Leu & - & $525-$ Leu & $524-$ His & - \\
- & - & $536-$ Leu & - & - \\
\hline $\begin{array}{c}\text { Jumlah } \\
\text { Ikatan }\end{array}$ & 1 & 2 & 1 & 1 & 4 \\
Hidrogen & & & & & \\
\hline
\end{tabular}

Hasil docking molekular menunjukkan bahwa dibandingkan dengan ligan lain, kuinin memberikan $\Delta G$ paling negatif dan ki paling kecil. Hal tersebut menunjukkan bahwa kuinin memiliki afinitas paling tinggi dibandingkan turunan kuinolin lainnya terhadap ER-a. Pada setiap ligan, terdapat 2 residu asam amino yang selalu berinteraksi dengan ligan yaitu 346-Leu dan 350-Ala (warna hijau pada tabel 3). Selanjutnya dilakukan perbandingan hasil redocking 4hidroksitamoksifen dengan docking kuinin terhadap ER- $\alpha$.

Tabel 4. Perbandingan hasil redocking 4hidroksitamoksifen dan docking kuinin terhadap ER- $\alpha$

\begin{tabular}{|c|c|c|}
\hline Ligan & 4-hidroksitamoksifen & Kuinin \\
\hline$\Delta \mathrm{G}(\mathrm{kcal} / \mathrm{mol})$ & $-11,91$ & $-8,73$ \\
\hline $\mathrm{ki}(\mu \mathrm{M})$ & 0,00185 & 0,398 \\
\hline & $343-\mathrm{Met}$ & $343-\mathrm{Met}$ \\
& $346-$ Leu & $346-$ Leu \\
& $347-\mathrm{Thr}$ & - \\
& $350-\mathrm{Ala}$ & $350-\mathrm{Ala}$ \\
Residu & $351-$ Asp & - \\
Asam & $353-\mathrm{Glu}$ & $353-\mathrm{Glu}$ \\
Amino & $383-\mathrm{Trp}$ & - \\
& $384-$ Leu & - \\
& $387-$ Leu & $387-$ Leu \\
& - & $388-\mathrm{Met}$ \\
& - & $391-$ Leu \\
\hline
\end{tabular}

\begin{tabular}{|c|c|c|}
\hline & 394-Arg & - \\
& - & $420-$ Gly \\
& $421-$-Met & - \\
& - & $424-$ Ile \\
& 428 -Leu & 428 -Leu \\
& $521-$ Gly & $521-$ Gly \\
& - & $524-$-His \\
& - & $525-$ Leu \\
\hline Jumlah & 2 & 1 \\
Ikatan & & \\
Hidrogen & & \\
\hline
\end{tabular}

Pada tabel 4 terlihat bahwa afinitas yang ditunjukkan oleh kuinin terhadap ERa lebih rendah dibandingkan 4hidroksitamoksifen. Dari 13 residu asam amino yang berinteraksi pada 4hidroksitamoksifen ada 7 asam amino yang juga berinteraksi dengan kuinin (warna hijau pada tabel 4). Sebanyak 12 asam amino memiliki interaksi yang berbeda antara 4-hidroksitamoksifen dan kuinin (warna kuning pada tabel 4), yang menunjukkan perbedaan jenis interaksi yang terjadi. Untuk jumlah ikatan hidrogen yang terbentuk tidak berbeda jauh antara 4-hidroksitamoksifen dan kuinin yaitu secara berturut-turut 2 banding 1 .

Menarik untuk dicermati adalah jumlah residu asam amino antara 4hidroksitamoksifen dengan kuinin samasama berjumlah 13 , namun afinitas yang ditimbulkan berbeda jauh. Hal tersebut mengindikasikan beberapa asam amino memberikan peranan penting terhadap afinitas ligan pada ER- $\alpha$. 4hidroksitamoksifen memiliki lebih banyak jumlah interaksi pada asam amino posisi 
346-353 dimana terdapat 5 interaksi dibandingkan 3 interaksi pada kuinin. Sebaliknya pada kuinin interaksi banyak terjadi pada asam amino posisi 521-525 dengan 3 interaksi berbanding 1 interaksi pada kuinin. Hasil visualisasi perbandingan dapat dilihat pada gambar 2 .

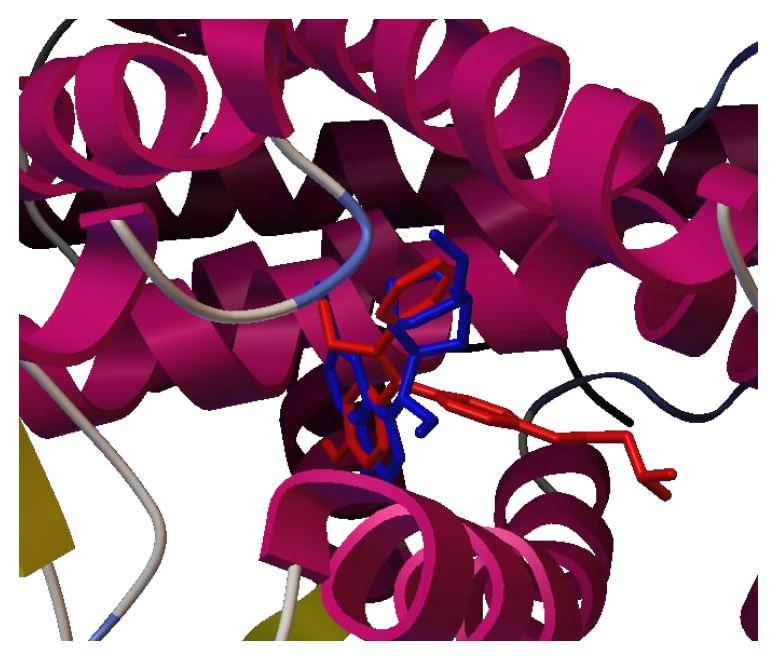

Gambar 2. Overlay perbandingan hasil redocking 4-hidroksitamoksifen dengan hasil docking kuinin (Merah = 4-hidroksitamoksifen; Biru = Kuinin)

Hasil perbandingan visual menunjukkan terdapat perbedaan orientasi pada 4-hidroksitamoksifen dengan kuinin. 4-hidroksitamoksifen memiliki rantai yang mengarah keluar dari kantung aktif ER- $\alpha$ yang selanjutnya dapat berinteraksi dengan air permukaan pada ER- $\alpha$, yang mana akan memperkuat interaksi antara 4hidroksitamoksifen dengan ER-a. Sementara kuinin seluruh bagiannya terdapat pada kantung aktif. Dari hasil visualisasi dapat disimpulkan bahwa meskipun sama-sama dapat berinteraksi dengan ER-a, 4-hidroksitamoksifen memiliki afinitas yang lebih tinggi dibandingkan kuinin. Untuk meningkatkan afinitas kuinin terhadap ER- $\alpha$, perlu dilakukan modifikasi struktural pada kuinin untuk dapat berinteraksi lebih khususnya pada asam amino posisi 346-353.

\section{KESIMPULAN}

Beberapa antimalaria golongan kuinolin diprediksi memiliki aktivitas sebagai antagonis ER- $\alpha$ dengan kuinin diprediksi memiliki afinitas paling tinggi dibandingkan turunan kuinolin lainnya. Meski demikian, afinitas yang ditunjukkan masih lebih rendah jika dibandingkan dengan 4-hidroksitamoksifen selaku salah satu terapi lini pertama untuk kanker payudara ER+. Untuk meningkatkan potensi antagonis ER- $\alpha$ dari kuinin perlu dilakukan modifikasi struktural untuk meningkatkan interaksi lipofilik dari kuinin terutama dengan domain 346-353 dari ERa.

\section{DAFTAR PUSTAKA}

Moverare-Skrtic, S., Borjesson, A.E., Farman, H.H., Sjorgen, K., Windahl, S.H., Lagerquist, M.K., Andersson, A., Stubelius, A., Carlsten, H., Gustafsson, J., Ohlsson, C. 2013. The Estrogen Receptor Antagonist ICI 182.780 can Act Both as an Agonist and an Inverse Agonist when Estrogen Receptor a AF-2 is Modified. Proceedings of the National Academy of Sciences. Vol. 111. No. 3. 1180-1185.

Pinhel, I., Hills, M., Drury, S., Salter, J., Sumo, G., A'Hem, R., Bliss, J.M., Sestak, I., Cuzick, J., Barrett-Lee, P., Harris, A., Dowsett, M. 2012. ER dan HER2 Expression are Positively Correlated in HER2 non-overexpressing Breast Cancer. Breast Cancer Research. Vol. 14. R46.

Yamamoto-lbusuki, M., Arnedos, M., Andre, F. 2015. Targeted Therapies for ER+/HER2- 
Metastatic Breast Cancer. BMC Medicine. Vol. 13. 137.

Liu, C.Y., Hung, M.H., Wang, D.S., Chu, P.Y., Su, J.C., Teng, T.H., Huang, C.T., Chao, T.T., Wang, C.Y., Shiau, C.W., Tseng, L.M., Chen, K.F. 2014. Tamoxifen Induces Apoptosis Through Cancerous Inhibitor of Protein Phospatase 2A-dependent Phospo-Akt Inactivation in Estrogen Receptor-negative Human Breast Cancer Cells. Breast Cancer Research. Vol 16. 431.

Kumar, S., Bawa, S., Gupta, H. 2009. Biological Activities of Quinoline Derivatives. Mini-Reviews in Medicinal Chemistry. Vol 9. 1648-1654.

Golden, E.B., Cho, H.Y., Hofman, F.M., Louie, S.G., Schonthal, A.H., Chen, T.C. 2015. Quinoline-based Antimalarial Drugs: a Novel Class of Autophagy Inhibitors. Neurosurgical Focus. Vol 38. No 3. E12.

Krishnaveni, M., Suresh, K., Arunkumar, R. 2016. Anti-proliferative and Apoptotic Effects of Quinine in Human Hep-2 Laryngeal Cancer and KB Oral Cancer Cell. Bangladesh Journal of Pharmacology. Vol. 11. 593-602.

Singh, Sandeep K. \& Singh, Shaija. 2014. A Brief History of Quinoline as Antimalarial Agents. International Journal of Pharmaceutical Sciences Review and Research. Vol 25. No 1. 295-302.

Mansel, R., Goyal, A., Le Nestour, E., MasiniEteve, V., O'Connel, K. 2007. A Phase II Trial of Afimoxifene (4-hydroxytamoxifen gel) for Cyclical Mastalgia in Premenopausal Women. Breast Cancer Research and Treatment. Vol 106. No 3. 389-397.

Morris, G. M., R.Huey, W.Lindstrom, M.F.Sanner, R.K.Belew, D.S.Goodsell, A.J.Olson. 2009. Autodock4 and AutoDockTools4: Automated Docking with Selective Receptor Flexiblity. Journal of Computational Chemistry. Vol 16. 2785-2791.

Kontoyianni, M., McClellan, Sokol. 2004. Evaluation of Docking Performance : Comparative Data on Docking Algorithm. Journal of Medicinal Chemistry. Vol 47. 558565.

Bissantz, C., G.Folkers, D.Rognan. 2000. Protein-based Virtual Screening of Chemical Databases : Evaluation of Different Docking/Scoring Combinations. Journal of Medicinal Chemistry.Vol 43. 4759-4767.

Cosconati, S., S.Forli, A.L.Perryman, R.Harris, D.S.Goodsell, A.J.Olson. 2010. Virtual Screening with AutoDock : Theory and
Practice. Expert Opinion Drug Discovery. Vol 5. No 6. 597-607.

O'Boyle, N., M.Banck, C.A.James, C.Morley, T.Vandermeersch, G.R.Hutchison. 2011. Open Babel : AN Open Chemical Toolbox. Journal of Chemoinformatics. Vol 3. No. 33.

Pratama, M.R.F. 2015. Molecular Docking of Anticanced Agents: Artemsinin and Derivatives as HER2 Inhibitor. Proceedings of 1st Sari Mulia International Conference on Health and Science 2015. Banjarmasin.

Nurhayati, B., Wibowo, M.S., Widyastuti, Y., Erawijantari, P.P., Widowati, W., Pratama, M.R.F., Gusdinar, T. 2015. In silico Analysis of Plantaricin EF that Expressed by Plasmid-Associated Bacteriocin Production Gene of Lactobacillus plantarum IBL-2 for Anti-Candida Agent Potential. Research Journal of Microbiology. Vol. 10. No. 12. 582-591.

Pratama, M.R.F. 2016. Akar kuning (Arcangelisia flava) sebagai inhibitor EGFR: Kajian in silico. Jurnal Farmagazine. Vol. 3 No. 1. 6-16. 